Д.А. Гриб, Б.О., Демідов, К.К. Кулагін, О.О. Хмелевська

Харківський національний університет Повітряних Сил ім. І. Кожедуба, Харків

\title{
ПРОБЛЕМНІ АСПЕКТИ НАУКОВО-ТЕХНІЧНОГО СУПРОВОДЖЕННЯ ПРОЦЕСУ УПРАВЛІННЯ ПОВНИМ ЖИТТЄВИМ ЦИКЛОМ СКЛАДНИХ ЗРАЗКІВ ОЗБРОЄННЯ I ВІЙСЬКОВОї ТЕХНІКИ
}

\begin{abstract}
У статті у систематизованому вигляді подані основні проблемні аспекти, що вирімують у провідних краӥнах світу, при науково-технічному супроводженні процесу управління повним життєвим ииклом (ЖЦ) складних зразків озброєння і військової техніки (ОВT). Розглянуті особливості побудови системи управління повним ЖЦ. Виділені такі важливі властивості системи і ї̈ процесу управління як можливість простежування стану зразка ОВТ на усіх стадіях його ЖЦ та ощадливості усіх стадій ЖЦ в иілому. Поданні деякі доцільні підходи до послаблення негативного впливу факторів ризику, що виникають як на стратегічному, так і на оперативному рівнях управління. Позначено, що розробка і використання автоматизованих систем управління повним ЖЦ зразків ОВТ можуть бути визнані перспективним напрямком оптимізації витрат ресурсів на підтримку необхідного рівня якості системи озброєння збройних сил держави у цілому і ї̈ основних підсистем. Доведена необхідність оперативного реагування на ситуаиії, що виникають, і підтримання при цьому стратегічної спрямованості управління повного ЖЦ зразків ОВТ, ще потребує узгодженого програмно-иільового і ситуаційного управління ЖЦ у межах єдиного програмно-ситуаційного підходу до управління, разом із створенням інформачійного середовища повного ЖЦ і міжвідомчих нормативних документів (стандартів), що визначають концептуальну, функиіональну і інформаџійну моделі системи управління ПЖЦ. Управлінські рімення щодо формування змісту і тривалості ЖЦ і переходу до наступних його стадій мають забезпечувати ощадливість ЖЦ систем озброєння збройних сил в иілому.
\end{abstract}

Ключові слова: повний життевий цикл зразка ОВТ, система управління повним життєвим циклом, ощадливість життевого циклу, простежуваність життєвого иџклу, стратегічний (оперативний) рівень управління.

\section{Вступ}

Постановка проблеми. Розвиток систем озброєнь збройних сил (СО) країн у світі все більше залежить від зростання вартості їх життєвих циклів (ЖЦ) і обсягів оборонних (воєнних) бюджетів країн. Виокремилось проблемне питання підвищення ефективності управління повним ЖЦ (ПЖЦ) складних і високотехнологічних зразків ОВТ (СВЗОВТ), при якому управління ПЖЦ окремих зразків ОВТ є взаємно узгодженим і синхронізованим 3 динамікою змін стану СО у цілому [1-9].

Аналіз останніх досліджень і публікацій. У результаті досліджень процесу управління ПЖЦ сформовані принципи системного підходу і вимога до його наскрізного простежування. Для ПЖЦ СВЗОВТ як об'єкту управління характерним $є$ інтегрована взаємодія усіх організацій, установ і підприємств, що задіяні у плануванні розробки, розробці, виробництві, ремонті, модернізації, експлуатації у сервісному обслуговуванні і утилізації, а також науково-технічному супроводженні [3;10-13]. На рис.1. наведені основні елементи системи управління ПЖЦ ОВТ.
В Україні розроблено ряд основних стандартів, які визначають порядок організації виконання та зміст конкретних видів діяльності на типових стадіях ЖЦ ОВТ, функції (взаємовідносини) основних виконавців та учасників робіт, фази (етапи) робіт та їх зміст [14-16] та проведена їх адаптація до міжнародних вимог і стандартів НАТО ААР-20, ААР-48 [17-19].

Разом з цим складність процесу управління ЖЦ OBT вимагає системного розвитку науковометодичного апарату для забезпечення врахування багатьох видів діяльності великої кількість різних суб'єктів ЖЦ (замовників, розробників, виробників, постачальників, субпостачальників, експлуатантів тощо) 3 метою досягнення оптимальних показників ефективності виконання програм озброєння, програм військово-технічного співробітництва, розвитку оборонно-промислового комплексу (ОПК) при мінімізації витрат на ПЖЦ ОВТ [20-21].

При цьому за поняттям управління ПЖЦ ОВТ розуміється сукупність взаємопов'язаних процесів створення і послідовної зміни стану оборонної продукції (систем, комплексів, зразків ОВТ) від початку дослідження та обгрунтування розроблення (модер- 
нізації) до зняття іï з експлуатації та безпечної утилізації. Процес управління ПЖЦ ОВТ спрямований на: оптимізацію властивостей ОВТ по критеріях ефективності, вартості та якості; узгодження бізнеспроцесів і процедур управління впродовж ЖЦ; забезпечення ефективного використання і координації ресурсів, інформації і технологій на протязі усього ЖЦ ОВТ [3; 10].У нормативних документах (аналіз яких ретельно проведений у ряді досліджень [3]) не встановлені у необхідному і узгодженому з сучасними тенденціями розвитку ОВТ обсязі порядок і склад інформаційного забезпечення органів військового управління (ОВУ), що забезпечують системний контроль стану ОВТ [21-23]. Тому для Збройних Сил України залишається актуальним дослідження вдосконалення науково-методичного апарату супроводження системи управління ПЖЦ зразків ОВТ, який забезпечить охоплення необхідних параметрів системи, способи та технології управління, оцінювання ефекту від управління, формування пропозицій до управлінських рішень на різних періодах ЖЦ.

Мета статті: подати у систематизованому вигляді основні проблемні аспекти, що виникають при науковому супроводженні процесу управління ПЖЦ $\mathrm{CO}$, розглянути особливості побудови відповідної системи управління і подати деякі економічно прийнятні підходи до послаблення негативного впливу факторів ризику на стратегічному і на оперативному рівнях управління.

\section{Виклад основного матеріалу}

В управлінні ЖЦ можна виділити дві основні складові частини:

- перша - діяльність 3 використанням управлінських технологій, що включає: управління вимогами; управління конфігурацією; проектний менеджмент; управління вартістю життєвого циклу; управління якістю оборонної продукції; управління ризиками і ресурсами; інтегровану логістичну підтримку; управління надійністю і технічною готовністю ОВТ з тривалими ЖЦ в умовах природного зменшення доступності комплектуючих, які зняті 3 виробництва тощо;

- друга - діяльність з використанням інформаційних технологій підтримки ЖЦ, таких як: нормативне забезпечення, методи, методики, методологія, програмні і технічні засоби, за допомогою яких здійснюється інформаційна підтримка ПЖЦ.

Необхідно розділяти систему управління ПЖЦ:

- на стратегічному рівні для наскрізного науково-технічного супроводження ПЖЦ зразків ОВТ 3 урахуванням їх місця і ролі у системі озброєння у цілому на довгострокову перспективу;

- на оперативному рівні для реалізації ЖЦ зразка ОВТ на короткострокову перспективу, який має, 3 одного боку, враховувати стратегічний план (бути узгодженим 3 ним), а з іншого - підтримувати прийняті управлінські рішення 3 протидії негативним ситуаціям [10].

Інформаційно-методичне забезпечення процесу планування ЖЦ має бути таким, щоб забезпечувалось формування управлінських рішень на єдиній концептуальній, науково-методичній, інформаційній основі шляхом реалізації з системних позицій наскрізних для ПЖЦ інформаційних технологій формалізації процесів і підтримки процедур формування управлінських рішень.

Для організації такого інформаційно-методичного забезпечення має бути створена інформаційна модель ЖЦ зразка ОВТ з відображенням його стану у інформаційному просторі загальної СО, визначені параметри управління ЖЦ (якості, надійності, вартості, часу та оцінки ризиків) на усіх періодах його реалізації (рис.2). Для цього необхідно вирішити проблеми і задачі за наступними напрямками:

- розробка методологічної концепції реалізації принципів системного підходу до вирішення задач наскрізного управління ПЖЦ зразків ОВТ з упорядкуванням виконання процедур, що використовують методи і прийоми формування управлінських рішень у вигляді єдиної технології системного аналізу 3 використанням об'єктивно-суб'єктивних моделей прийняття рішень, що об'єднують об'єктивну оцінку i експертні дані, адекватні задачам управління i відповідному інформаційно-методичному забезпеченні;

- розробка системно-концептуальної моделі управління типовим ЖЦ зразка ОВТ, що відображає системні взаємозв'язки між об'єктами, суб'єктами і процесом управління, що $є$ основою для розробки механізму управління ЖЦ зразків ОВТ у межах програмних комплектів, що формуються за програмно-цільовим методом плануванням розвитку ОВТ;

- розробка моделі і методики (механізму) управління ЖЦ зразків ОВТ для зниження (попередження) негативних проявів факторів ризику у процесі реалізації ЖЦ, що пов'язані 3 невизначеністю змін зовнішнього середовища;

- розробка системно-концептуальних основ побудови системи інформаційно-методичного забезпечення управління ЖЦ зразків ОВТ при їх науково-технічному супроводженні;

- обгрунтування принципів побудови і структури автоматизованої інформаційної системи (AIC) підтримки прийняття планових управлінських рішень, що формуються і реалізуються при управлінні ЖЦ зразків ОВТ;

- розробка комплексу моделей, методичних i інформаційних засобів підтримки прийняття рішень, що формуються і реалізовуються при управлінні ЖЦ зразків ОВТ; 


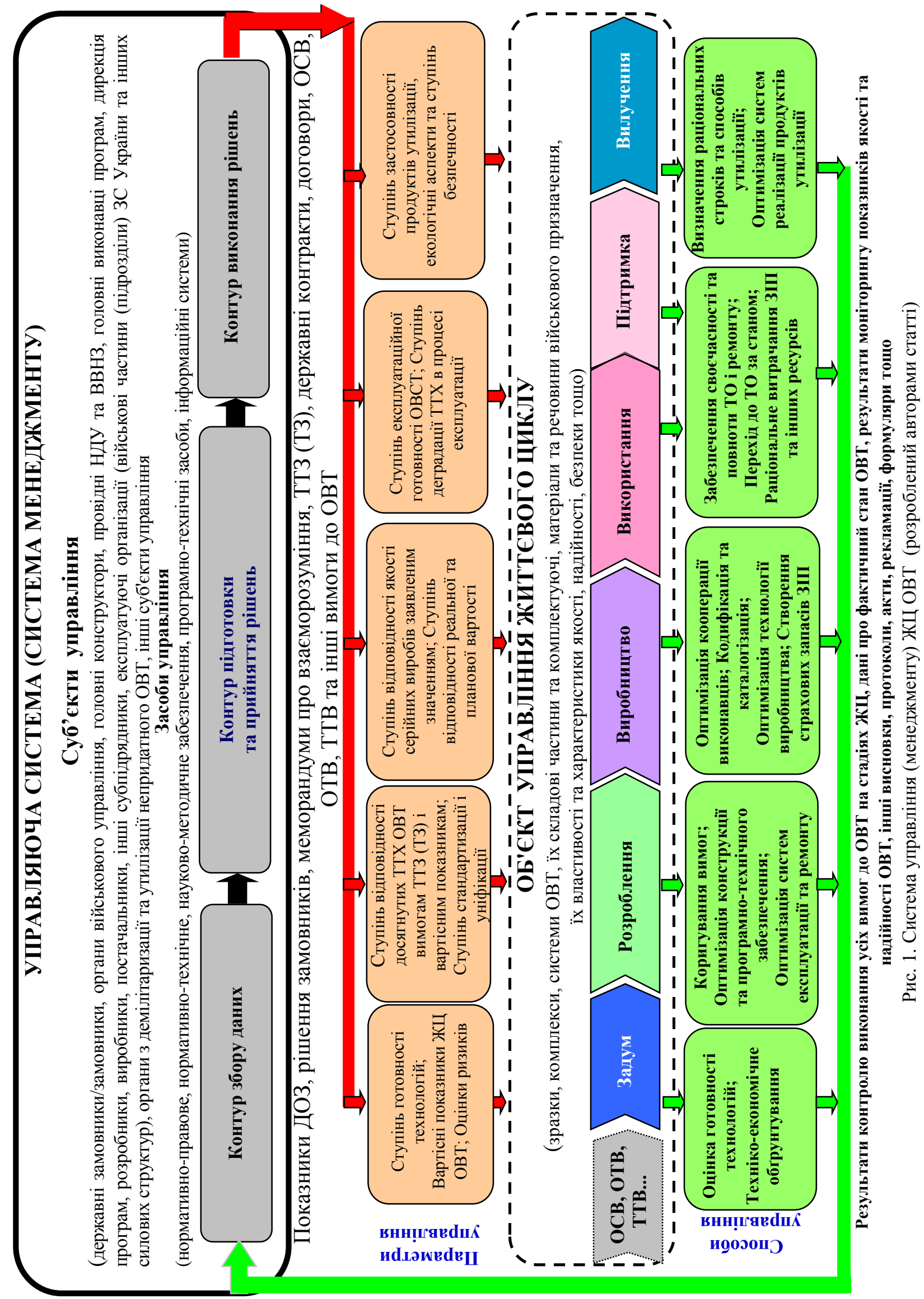


- розробка комплексної методики інформаційно-методичного забезпечення управління ЖЦ зразків ОВТ 3 використанням програмно-технічних засобів автоматизації процесів формування планових управлінських рішень;

- обгрунтування, аналіз і розробка принципів побудови i функціонування програмно-технічних засобів автоматизації процедур підготовки рішень, що приймаються і реалізуються у процесі управління ЖЦ зразків ОВТ.

Для врахування особливостей управління ПЖЦ зразків ОВТ необхідно проведення досліджень за наступними напрямками:

- обгрунтування (формування) поняття обліку системи управління ПЖЦ СВЗОВТ, визначення іiі структури, функцій, вирішуваних задач, взаємозв'язків, кооперацій виконавців, їх функцій і повноважень;

- створення моделі інтегрованого інформаційного середовища, протоколів, форматів, процедур необхідних для забезпечення функціонування AIC;

- формування технологій управління ПЖЦ зразків ОВТ (інформаційної підтримки ЖЦ зразків ОВТ, проектування, моделювання, виробництва, забезпечення експлуатації тощо);

- формування технологій оцінювання впливу прямих і непрямих (позитивних і негативних) впливів на зміни вартості ЖЦ у різних його періодах [310].

Реалізація вимог до ощадливості ПЖЦ СВЗОВТ має забезпечувати прийнятні 3 воєнноекономічної точки зору $[10,20,24]$ витрати на усіх його періодах (рис.2) та відбір найкращих з можливих варіантів конструктивно-технологічного виконання. Усі процеси управління ПЖЦ зразків ОВТ, а також параметри стану ПЖЦ мають бути цілеспрямовано керованими в рамках системи управління за усіма важливими параметрами ПЖЦ цих зразків (рис. 3) [3; 10-11].

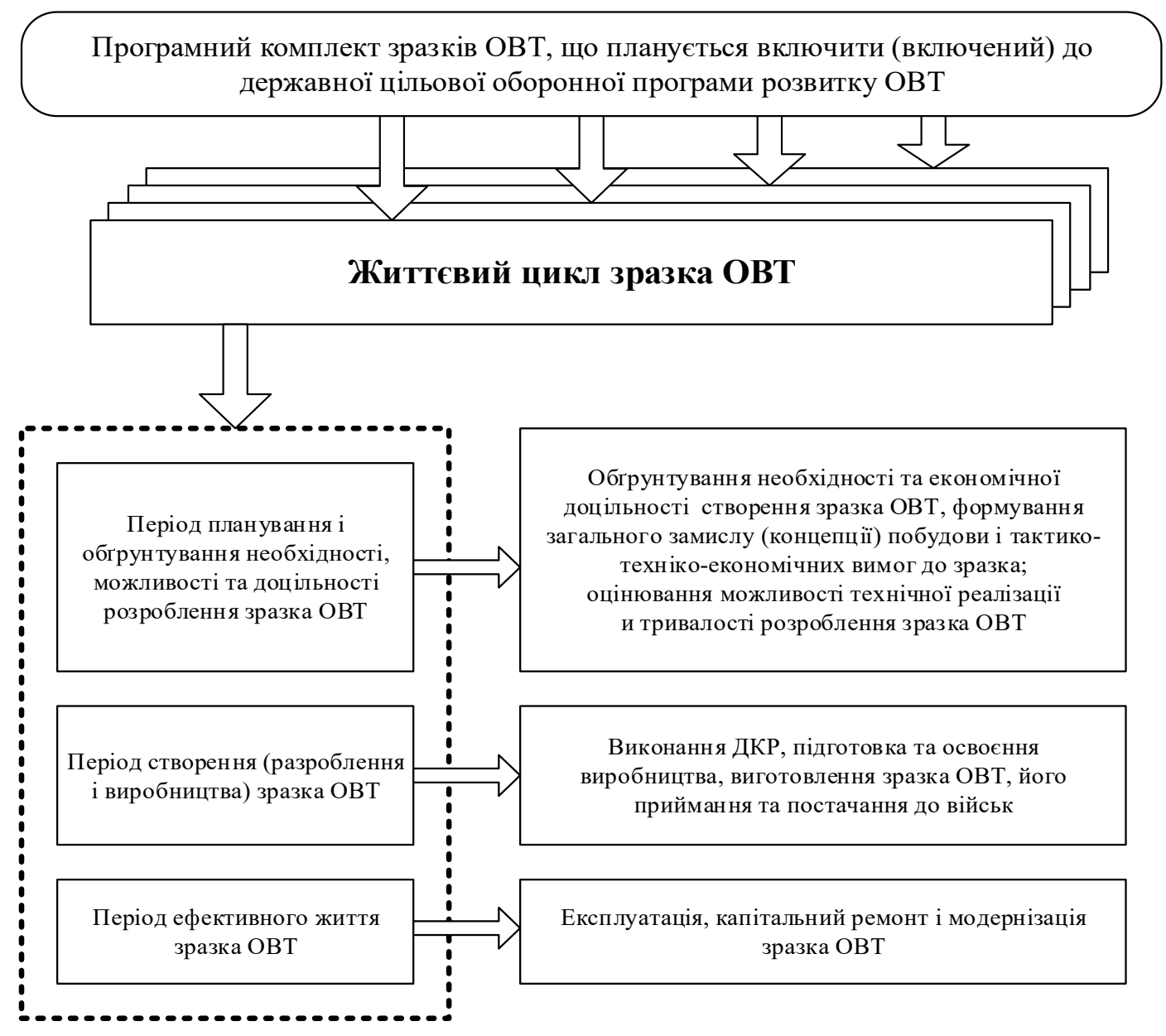

Рис. 2. Основні періоди реалізації життєвого циклу зразка ОВТ Джерело: [10, С. 303]

Наприклад, в оборонних проектах НАТО, вартість ЖЦ будь якого зразка ОВТ розраховується на початкових стадіях ЖЦ на єдиній методологічній основі (NATO Common Life Cycle Cost (LCC)
Methodology) створеної зусиллями фахівців Групи 3 управління життєвим циклом озброєнь Конференції національних директорів з озброєнь НАТО (АС/327 LCMG), Організації НАTO з управління програмою 
створення авіаційної системи дальнього радіолокаційного виявлення та управління (NATO Airborne Early Warning and Control Programme Management Organization, NAPMO), Агенції НАТО з підтримки та постачання (NATO Support Agency, NSPA), Агенції НАТО з питань обслуговування систем інформації та звязку (NATO Communications and Information Agency, NCIA), Агенції НАTO з управління розробкою, виробництвом та логістичною підтримкою літаків-винищувачів Єврофайтер-2000 та Торнадо (NATO Eurofighter and Tornado Management Agency,
Прикладом, успішного застосування зазначеної методології є багатонаціональні проекти створення багатоцільового винищувача Eurofighter Typhoon, військово-транспортного літака А400M, багатонаціонального багатоцільового транспортний літаказаправника Airbus A330 MRTT), модернізації літаків NE-3 AWACS, розробки радару RAT31DL для системи повітряного спостереження за наземною обстановкою (Allied Ground Surveillance, AGS), створення бронетранспортеру “Вохег” та інші. NETMA).

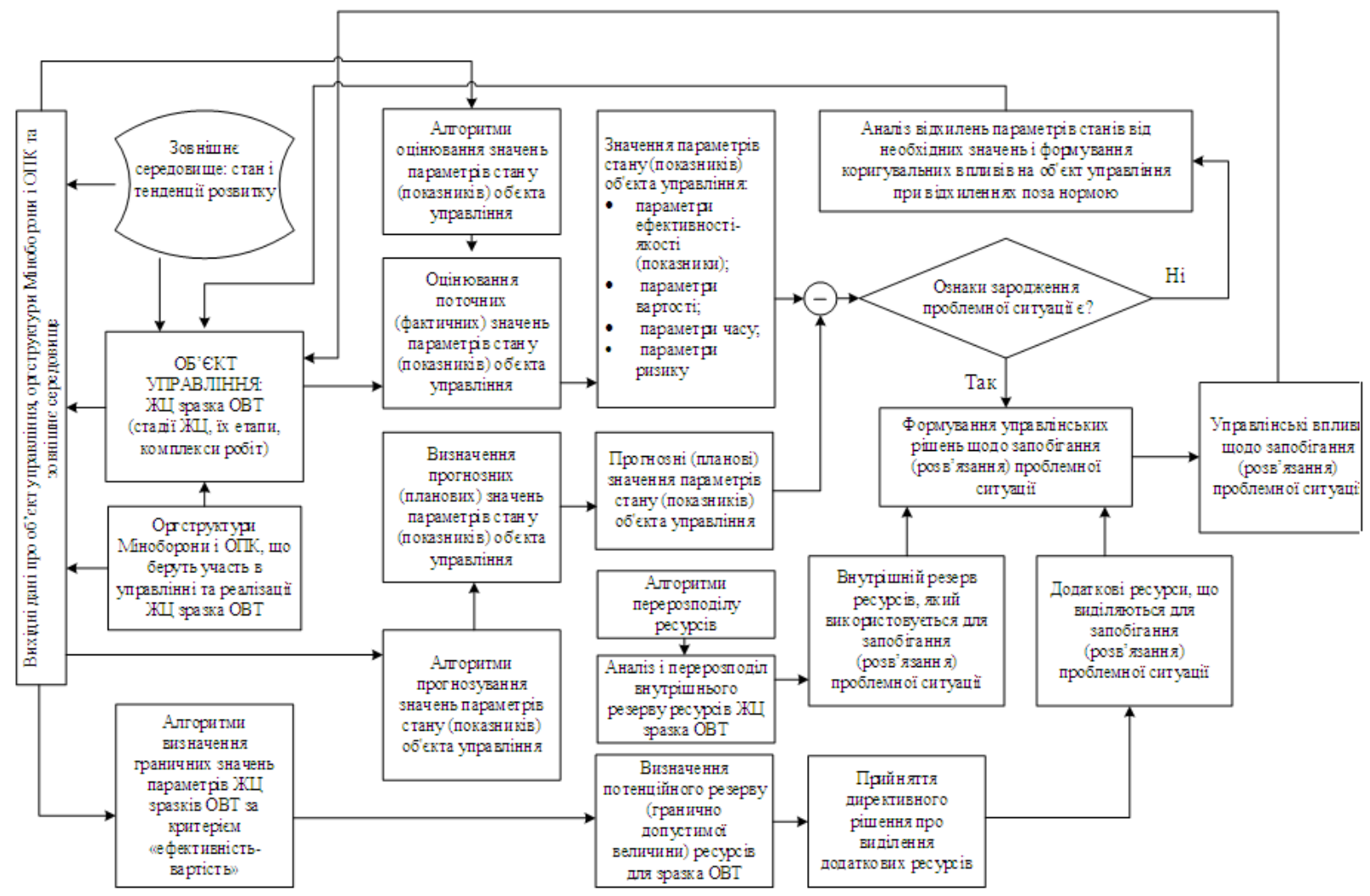

Рис. 3. Схема управління основними параметрами стану ЖЦ зразка ОВТ Джерело: [10, С. 316]

За рахунок системного аналізу та вартісного менеджменту, стало можливим на $30 \%$ скоротити бюджет програми створення літака-винищувача F35 , який спочатку перевищував один трильйон доларів США.

Нормативна база з управління ПЖЦ у НАТО періодично вдосконалюється. У теперішній час переглядаються: стандарт ALCCP-1 "Настанова НАТО з оцінки вартості життєвого циклу” [25] 3 урахуванням останніх версій AAP-20, AAP-48, ALP10 та інтеграції специфікацій Організації 3 досліджень i технологій (Research and Technology Organisation, RTO) RTO-TR-SAS-069 Code of Practice for Life Cycle Costing (Кодекс усталеної практики щодо оцінки вартості життєвого циклу), RTO-TR-SAS-076 NATO Independent Cost Estimating and the Role of the Life Cycle Costs Analysis in
Managing the Defence Enterprise (Незалежна оцінка витрат та роль аналізу вартості життєвого циклу в управлінні оборонним підприємством), RTO-TR058/SAS-028 Cost Structure and Life Cycle Costs for Military Systems (Структура витрат упродовж життєвого циклу продукції військового призначення) та RTO-TR-054 Methods and Models for Life Cycle Costing (Методи та моделі визначення витрат). ALCCP-1 $є$ сучасним методологічним інструментом, що використовується експертами НАТО для підтримки прийняття рішень у національних та спільних програмах озброєнь з метою зменшення часу виконання державних та міжнародних оборонних замовлень, а також для забезпечення їх ефективності.

Одним $з$ важливих елементів забезпечення якості і зниження вартості ПЖЦ СВЗОВТ є їх наскрізна простежуваність. 
На стадії розробки зразка ОВТ має забезпечуватись простежуваність вимог до нього і результатів розробки у вигляді конструктивно-технічних характеристик та результатів випробувань, що необхідні для підтвердження відповідності ОВТ встановленим обов'язковим і додатковим вимогам. На цій же стадії здійснюється проектування ощадливого ЖЦ.

Ощадливість виконання проектно-конструкторських робіт може бути досягнута за рахунок:

- використання напрацювань, що отримані на етапах створення науково-технічного доробку, а також запозичення передових рішень, що отримані при виконанні інших НДР і ДКР;

- використання в організаціях промисловості методології проектування, що забезпечує лінійність процесу проектування як процесу послідовного прийняття рішень при виконанні проектноконструкторських робіт.

На етапі проектування складних технічних виробів задається концепція експлуатації, а у конструкції і компоновці зразка реалізуються відповідні конструктивно-технічні рішення.

На стадії виробництва простежуваність якості і кількості матеріалів, створення обсягів запасів, виготовлення напівфабрикатів, відбракування продукції, відповідності документації, інструментів, приладдя і обладнання має забезпечувати ефективний менеджмент якості ОВТ і скорочення витрат виробництва. На цій стадії кожній з вказаних складових зразка ОВТ має бути наданий унікальний номер або штрих-код, за яким у подальшому вони будуть ідентифікуватись та простежуватись протягом ПжЦ.

Забезпечення ощадливості на стадії серійного виробництва забезпечується шляхами: організації роботи підрозділу з розробки і втілення заходів, що забезпечують ощадливість виробництва, планування ощадливого виробництва у програмі розвитку підприємства, розробки стандартів організації системи менеджменту якості забезпечення робіт із створення, розвитку і функціонування ощадливого виробництва.

На після виробничих стадіях простежуваність OBT має забезпечуватись шляхом отримання і накопичення достовірних даних про: походження виробів, їх матеріалів і комплектуючих, місцезнаходження виробів та його зміни після постачання, даних про напрацювання, обслуговування, ремонт, зміни конфігурації і комплектації, доробок. Це забезпечить ефективне управління поставками, експлуатації, ЖЦ виробів у цілому і надає вихідні дані для планування заходів підвищення надійності, безпеки, технологічності і ремонтопридатності, мінімізації вартості ЖЦ зразка ОВТ, протидії незаконному обороту виробів, тощо.

Крім того, на усіх стадіях ЖЦ зразків ОВТ має забезпечуватись метрологічна простежуваність, яка міститься у документуванні умов, засобів, методик вимірювань характеристик ОВТ.

Практична діяльність 3 розробки ощадливого ЖЦ складного зразка ОВТ залежить від:

- потрібного обліку зразка ОВТ;

- конкретного розробника зразка і його компетенції, оснащення, науково-технічного задуму та іншого;

- конкретного серійного підприємствавиробника зразка з усім його оснащенням, організацією, кадровим потенціалом і іншим;

- конкретного рівня розвитку і підготовленості експлуатантів і організації утилізації.

Логістика управляє апаратним і матеріальним забезпеченням при виконанні зразком ОВТ свого функціонального призначення і у широкому розумінні розглядається як комплекс засобів забезпечення використання за призначенням складного технічного виробу на протязі усього терміну експлуатації. На іiі основі може бути організована ощадлива експлуатація.

У світовій практиці широко використовується концепція технологічного обслуговування складних технічних виробів під назвою "Інтегрована/комплексна логістична підтримка" (Integrated Logistics Support, ILS) [19]. До кінця 2020 року планується перегляд союзницької публікації НАТО ALP-10 з урахуванням положень специфікацій Sсерії Європейскої Асоціації аерокосмічної та оборонної промисловості (AeroSpace and Defence Industries Association of Europe, ASD) та Американської Асоціації аерокосмічної промисловості (Aerospace Industries Association of America, AIA), a також технології автоматизації обміну даними (Data EXchange).

Ощадливість утилізації закладається на етапі проектування зразків ОВТ у відповідні проектноконструктивні рішення.

Ощадливість кожної стадії (етапу) ЖЦ зразка ОВТ має розглядатись як:

- економія сил та засобів при реалізації даних стадій (даного етапу);

- створення умов для економії засобів на наступних стадіях (етапах).

На протязі ПЖЦ СЗОВТ має здійснюватись його науково-технічне супроводження яке має охоплювати процеси планування, організації проведення і координації виконання заходів і робіт, обліку контролю і приймання їх результатів, що здійснюється під керівництвом замовника при безпосередній участі його наукових (випробувальних і інших) установ, підрозділів і служб у взаємодії з промисловими i іншими організаціями. Його основним призначенням є:

- скоординоване по цілях, задачах і виконанню, збалансоване по ресурсах ефективне управління 
діяльністю у воєнно-технічний області в цілому ЖЦ і рівнем якості супроводження зразків ОВТ, у тому числі і виконання їх проектів;

- контроль ходу і прийманням результатів виконання заходів і робіт, що проводяться як при плануванні розвитку ОВТ, так і на протязі усього ЖЦ зразків ОВТ, що супроводжується (бойових і забезпечення);

- відпрацювання відповідних управлінських рішень, що реалізується при технічному оснащенні збройних сил.

Основними цілями науково-технічного супроводження ПЖЦ СО є:

- ефективний контроль процесів планування розвитку ОВТ, виконання програм озброєння і державних оборонних замовлень, планів НДР і ДКР, ходу і результатів розробки ОВТ;

- реалізація планів виробництва, закупівля, постачання у війська ОВТ;

- будівництво об'єктів для монтажу зразків OBТ і забезпечення їх функціонування;

- розвиток випробувальної бази полігонів і дослідних центрів, а також рівня якості і ступеню виконання вимог до зразків ОВТ, для забезпечення прийняття обгрунтованих рішень 3 технічного оснащення збройних сил у процесі формування i реалізації програм озброєння;

- комплексне управління організаційнотехнічними заходами і якістю зразків ОВТ, при плануванні розвитку, розробки, виробництва, випробування, експлуатації, ремонту і модернізації OBT, що дозволяє систематично і своєчасно впливати на рівень якості зразків і під час формування, забезпечення, контролю, відновлення і підтримання ïx у потрібних межах на протязі усього ЖЦ.

Контроль ходу і результатів виконання організаційно-технічних заходів робіт в області науковотехнічного супроводження ПЖЦ систем ОВТ має охоплювати наступні основні напрямки діяльності і об'єкти контролю:

- проекти планів робіт різних рівнів і напрямків діяльності у воєнно-технічні області;

- звітну науково-технічну, проектну, робочу конструкторську і технологічну, експлуатаційну, ремонтну та іншу документацію на зразки ОВТ;

- обсяг робіт, що виконуються і терміни їх виконання;

- якість результатів робіт і рівні їх відповідності задачам (плановим) значенням;

- ступінь і своєчасність втілення (реалізації) отриманих результатів (у тому числі результатів науково-технічного і технологічного добутків) i ïx відповідності встановленим цілями і нормам;

- повноту і своєчасність ресурсного забезпечення цих робіт, у тому числі з виконання вимог по їх ощадливості;
- ступінь завершеності робіт до встановлених термінів;

- ступінь відповідності рівня досконалості зразка ОВТ досягненням науки, техніки і технологій, а також оперативно-тактичним і техніко-економічним вимогам міністерства оборони (замовників ОВТ) i тощо.

Для ефективного інформаційного забезпечення наукового супроводження процесу управління ПЖЦ OBT необхідна автоматизація процесу формування баз даних про стан окремих зразків, систему ОВТ, ресурси і логістику (рис.3) на усіх періодах ПЖЦ 3 необхідним рівнем повноти, актуальності і достовірності.

Порядок формування і використання бази даних має встановлюватись директивно для усіх суб'єктів процесу (рис. 1) [3; 10].

Інформаційна автоматизована система управління ПЖЦ ОВТ має забезпечувати оперативне вирішення таких задач, як: паспортизація техніки, планування трудових і матеріальних ресурсів, організації управління роботами в області технічного забезпечення військ (сил), формування усього спектру облікових, контрольних, звітних і плануючих документів, формування заявок, накопичення статистичних даних про експлуатацію і ремонт зразків OBT, формування висновків для розробників і постачальників ОВТ, забезпечення потрібної достовірності наукових прогнозів і висновків щодо ЖЦ ОВТ [2; 21-22].

У світовій практиці відомий досвід інтеграції інформаційного простору розробника, виробника, експлуатанта в межах ідеології PLM (управління ЖЦ продукції), яка забезпечує використання єдиних методик і засобів інформаційної підтримки виробів на протязі усіх періодів ЖЦ.

PLM це стратегія ведення бізнесу на основі системних бізнес-рішень, підтримуючих колективну розробку, управління, розповсюдження та використання інформації про специфікацію виробу в рамках розширеного міжгалузевого (або багатонаціонального) виробництва протягом ПЖЦ.

Формування інформаційного простору для забезпечення простежуваності ПЖЦ забезпечують наступні інформаційні системи:

- у “об'єднаних силах" НАТО використовується технологія єдиної унікальної ідентифікації (ототожнення) військового майна (Unique Identification (UID) of Items in NATO Connected Forces Initiative (CFI)) [26], що дозволяє на 95\% скоротити час на ідентифікацію необхідних матеріальних засобів, на $60 \%$ зменшити час на введення їх в експлуатацію та закріплення за підрозділами, на 15\% покращити інформованість про стан та якість військового майна, та інше; 
- автоматизована система управління конструкторськими даними про виріб (Product Data Management, PDM), які дозволяють зберігати дані про виріб (комп'ютерні CAD-моделі виробу та креслення, цифрові макети (DMU), специфікації матеріалів (BOM)) у базах даних. PDM дозволяє організувати спільний доступ до цих даних, забезпечуючи їх постійну цілісність, вносити необхідні зміни до усіх версій виробу, модифікувати специфікацію матеріалів, допомагати конфігурувати варіанти виробу.

В якості інтегруючої системи PDM використовується на протязі усього ЖЦ в рамках концепції управління ПЖЦ виробу (Product Life Cycle Management, PLM).

Крім технології автоматизованого проектування (Computer-aided design, CAD) на стадії "Розроблення" застосовують технології автоматизованого інженерного розрахунку, аналізу і симуляції фізичних процесів (Computer-aided engineering, CAE), автоматизованої підготовки виробництва (Computer-aided manufacturing, САМ) та технології безперервної інформаційної логістичної підтримки життєвого циклу (Continuous Acquisition and Life Cycle Support, CALS);

- автоматизовані системи планування та управління ресурсами підприємства (Enterprise Resource Planning, ERP), управління ресурсами (Material Requirements Planning, MRP), управління технологічними процесами (Manufacturing execution system, MES), управління матеріально-технічним забезпеченням підприємств (Supply Chain Management, $\mathrm{SCM})$, управління взаємовідносинами між суб'єктами ЖЦ, в першу чергу із замовниками (Customer relationship management, CRM);

- інформаційні технології підтримки ЖЦ (Product Life Cycle Support, PLCS), відомі як технології безперервної інформаційної логістичної підтримки ЖЦ (Continuous Acquisition and Life Cycle Support). PLCS/CALS-технології забезпечують вирішення таких завдань, як: накопичення, збереження та систематичне оновлення даних про виріб ОВТ, що отримуються протягом усього ЖЦ; узгодження, затвердження та систематичне відстежування виконання вимог до виробу ОВТ та його складових на усіх стадіях ЖЦ; паралельна розробка конструкції виробу та системи його експлуатації та подальшої утилізації; кодифікація та єдина унікальна ідентифікація продукції оборонного призначення; моніторинг стану виробу ОВТ в процесі експлуатації, що дозволяє накопичувати та аналізувати фактичні дані про надійність, витрати ресурсів усіх видів, ефективність застосування, збереження та транспортування; електронна технологія створення експлуатаційної та ремонтної документації про виріб ОВТ; стандартизація процесів і технологій управління ЖЦ та інформаційної взаємодії усіх суб'єктів управління ЖЦ;
- автоматизована інформаційна система тилового забезпечення збройних сил США, яка здійснюється в межах програми SALE (Single Army logistics Enterprise) та ідеології PLM, забезпечує всебічний моніторинг ресурсів і на усіх рівнях управління (стратегічному, оперативному, тактичному), реалізацію концепції адресного постачання зразків техніки, ресурсів, палива і боєприпасів, планування технічного обслуговування і ремонту ОВТ та інше.

Базові технології представлення даних та управління цими даними, а також інформаційні моделі для різних предметних галузей регламентовані відповідними стандартами.

Основним стандартом PLCS став стандарт ISO 10303-239 [27], який визначає процедури інформаційного обміну в ході підтримки життєвого циклу складних технічних систем. Зокрема, ISO 10303-239 підтримує не тільки обмін інформацією про склад та структуру виробу, але і обмін інформацією, необхідною для: опису виробу та його експлуатаційних можливостей, технічного обслуговування та ремонту виробу, управління конфігурацією протягом життєвого циклу, планування застосування виробу та документування історії самого виробу та досвіду його застосування.

Сучасні інформаційні системи забезпечують централізоване обслуговування баз даних про стан понад 30 мільйонів одиниць ОВТ і номерних їх комплектуючих від їх виробництва до утилізації. Кількість об'єктів обліку з часом передбачається довести до 100 мільйонів одиниць. У цілому, прийняті заходи дозволяють вести мову про забезпечення “повного” нагляду за військовим майном

Таким чином, вдосконалення процесу наукового супроводження процесу управління ПЖЦ систем OBТ шляхом його автоматизації $є$ перспективним напрямком оптимізації витрат ресурсів на розвиток i підтримання потрібного рівня технічного оснащення збройних сил і забезпечення необхідного рівня якості системи озброєння держави у цілому $[3 ; 10 ; 21 ; 24]$.

\section{Висновки}

Для системного охоплення усіх видів робіт протягом ЖЦ, необхідна централізована система управління ПЖЦ зразків ОВТ міжгалузевого рівня, рівня Міністерства оборони і нижче, що буде сприяти забезпеченню фінансових і матеріальних витрат на технічне оснащення збройних сил і підвищенню його якості і повноти.

На усіх стадіях (етапах) ЖЦ зразків ОВТ має забезпечуватись виконання вимог 3 наскрізного i поетапно узгодженого простежування результатів, що отримуються при науково-технічному супроводженні ПЖЦ ОВТ, з метою скорочення витрат фінансових і інших ресурсів. 
В управлінні ПЖЦ зразка ОВТ доцільно виділяти рівень стратегічного і оперативного управління. Стратегічне управління має охоплювати ПЖЦ СВЗОВТ у взаємодії з системою ОВТ, зразки якої у програмному періоді будуть знаходитись у різних станах їх ЖЦ.

У процесі реалізації ЖЦ у результаті впливу різних факторів, що виникають неминучі відхилення поточних результатів від потрібних (запланованих), що обумовлює необхідність оперативного управління ЖЦ зразка ОВТ. Оперативне управління має бути скоординованим із стратегічним і враховувати поточні ситуації, які не могли б бути передбаченими стратегічним планом 3 причини існуючої об'єктивної невизначеності.

При оперативному управлінні мають контролюватися поточні значення параметрів стану ЖЦ і відстежуватись динаміка змін впливів на хід реалізації ЖЦ зовнішніх факторів.

Необхідність оперативного реагування на ситуації, що виникають, і підтримання при цьому стратегічної спрямованості змін стану ПЖЦ СВЗОВТ потребує узгодженого програмно-цільового і ситуаційного управління, разом із створенням інтеграційного інформаційного середовища ПЖЦ і міжвідомчих нормативних документів (стандартів), що визначають концептуальну, функціональну і інформаційну моделі системи управління ПЖЦ.

Система управління ПЖЦ має забезпечувати відстежування станів зразків ОВТ, що супроводжуються на усіх стадіях його ЖЦ і реалізовувати управління таким переходом до наступних стадій, при якому забезпечується ощадливість ЖЦ в цілому.

\section{Список літератури}

1. Чепков І.Б. Теорія озброєння. Науково-технічні проблеми та завдання. Т.4. Воєннотехнічна політика провідних країн світу: монографія / І.Б. Чепков, В.В. Зубарєв, В.О. Смірнов. - К.: ВД Дмитра Бураго, - 2016. - 388 с.

2. Чепков І.Б. Теорія озброєння. Науково-технічні проблеми та завдання Т. 2. Військово-технічне співробітництво в системі забезпечення воєнної безпеки держави: монографія / І.Б. Чепков, В.В. Зубарєв, В.О. Смірнов. - К.: ВД Дмитра Бураго, 2015. - 404 c.

3. Чепков І.Б. Теорія озброєння. Науково-технічні проблеми та завдання. Т. 6. Воєнно-економічний аналіз життєвого циклу озброєння та військової техніки: теоретико-методологічні засади: монографія / І.Б. Чепков, В.В. Зубарєв, В.К. Борохвостов. - К.: ВД Дмитра Бураго, 2018. - 475 с.

4. Владимиров А.Н. Основы общей теории войны / А.Н. Владимиров. - М.: монография: в 2-х ч. - Часть I: Основы теории войны. - М.: МФПУ “Синергия”, 2013. - 832 с.

5. Владимиров А.Н. Основы общей теории войны / А.Н. Владимиров. - М.: монография: в 2-х ч. - Часть II: Основы теории, практики и искусства управления государством. - М.: МФПУ “Синергия”, 2013. - 976 с.

6. Карягин В.В. Военная политика и стратегия США в геополитической динамике XXI века: монография / В.В. Карягин, В.П. Козин. - М.: Граница, 2014. -368 с.

7. Федорович В.А. США: военная экономика (организация и управление) / В.А. Федорович, В.Б. Муравник, О.Н. Бочкарёв. - М.: Международные отношения, 2013. - 616 с.

8. Сидорин А.Н. Вооруженные силы США в ХХІ веке: военно-теоретический труд / А.Н. Сидорин, В.М. Прищепов, В.П. Акуленко. - М.: Кучево поле, 2013. - 800 с.

9. Высокие технологии в США: Опыт министерства обороны и других ведомств / Д.О. Рогозин, И.А. Шеремет, С.В. Гарбун, А.М. Губинский. - М.: Изд-во МУ, 2013. - 384 с.

10. Методические основы системных исследований и решения проблем технического оснащения вооруженных сил государства: монография. Книга 1 / Б.А. Демидов, О.П. Коростылев, С.Н. Остапенко, Д.А. Гриб; под ред. Б.А. Демидова, О.П. Коростылева - К.: Стилос, 2016. - 655 с.

11. Системно-концептуальные основы методологии военно-научных исследований и решения прикладных военнотехнических проблем: монография. Книга 2 / Б.А. Демидов, С.Н. Остапенко, М.И. Луханин, А.Ф. Величко и др.; под ред. Б.А. Демидова. - Тверь: ЗНПАО, 2014. - 688 с.

12. Буренок В.М. Методология обоснования перспектив развития средств вооруженной борьбы общего назначения / В.М. Буренок, А.В. Погребняк, А.М. Скотников. - М.: Машиностроение, 2010. - 368 с.

13. Журавлев А.В. Теория управления развитием вооружения / А.В. Журавлев. Часть 1. - М.: В.А. РВСН им. Петра Великого, 2002. - $221 \mathrm{c}$.

14. ДСТУ В-П 15.004:2019. Система розроблення і поставлення на виробництво озброєння та військової техніки. Стадії життєвого циклу озброєння та військової техніки.

15. ДСТУ ISO/IEC/IEEE 15288:2016. Інженерія систем і програмного забезпечення. Процеси життєвого циклу систем (ISO/IEC/IEEE 15288:2015, IDT);

16. ДСТУ ISO/IEC TS 24748-1:2018. Інженерія систем і програмних засобів. Керування життєвим циклом. Частина 1. Настанови щодо керування життєвим циклом (ISO/IEC TS 24748-1:2016, IDT).

17. AAP-20:2015 NATO Programme Management Framework (NATO Life Cycle Model).

18. AAP-48:2019 NATO System Life Cycle Processes.

19. ALP-10:2011 NATO Guidance on Integrated Logistic Support for Multinational Armament Programmes.

20. Гультяєв А.А. Проблеми ціноутворення на продукцію військового призначення та можливі підходи до їхнього розв’язання / А.А. Гультяєв, В.С. Сіренко, М.А. Чернега // Озброєння та військова техніка. - 2017. - № 4(16). - С. 11-19. 
21. Методологічні й системотехнічні аспекти інформаційного забезпечення управління системами військового призначення та діяльністю в оборонній сфері: монографія. Том 1 / Б.О. Демідов, О.Ф. Величко, Д.А. Гриб, М.І. Луханін, О.П. Коростельов та ін.; за ред. Б.О. Демидова, О.П. Клоростельова. - К.: Стилос, 2018. - 624 с.

22. Методика нечіткого оцінювання для систем підтримки прийняття проєктних рішень на етапах створення зразків озброєння і військової техніки / О.О. Гловін, М.В. Зірка, Н.П. Кадет, Н.М. Коцюруба // Озброєння та військова техніка. - 2019. - № 3(23). - С. 99-109.

23. Методичні рекомендації щодо формування методології воєнно-економічного обгрунтування (супроводження) програм розвитку Збройних Сил України / О.М. Семененко, О.Г. Водчиць, Р.В. Бойко, Ю.Б. Добровольський, С.С. Масловський, О.А. Корочкін // Системи озброєння і військова техніка. - 2018. - № 2(54). - С. 142-150. https://doi.org/10.30748/soivt.2018.54.20.

24. Методичні аспекти планування розвитку систем озброєння протиповітряної оборони в умовах ресурсного обмеження / О.В. Турінський, Б.О. Демідов, Д.А. Гриб, О.О. Хмелевська // Наука і техніка Повітряних Сил Збройних Сил України. - 2020. - № 1(38). - С. 61-71.

25. ALCCP-1:2008 NATO Guidance on Life Cycle Costs.

26. AUIDP-1 NATO Guidance on Unique Identification (UID) of Items Ed.B Version 1.

27. ISO 10303-239:2005 Industrial Automation Systems and Integration - Product Data Representation and Exchange Part 239: Application Protocol: Product Life Cycle Support.

\section{References}

1. Chepkov, I.B., Zubarev, V.V. and Smirnov, V.O. (2016), "Teoriya ozbroyennya. Naukovo-tekhnichni problemy ta zavdannya. T. 4. Voyennotekhnichna polityka providnykh krayin svitu: monohr" [Weapon theory. Scientific and technical problems and tasks. Vol. 4. Military policy of the leading countries of the world], Dmytro Burago Publishing House, Kyiv, 388 p.

2. Chepkov, I.B., Zubarev, V.V. and Smirnov, V.O. (2015), "Teoriya ozbroyennya. Naukovo-tekhnichni problemy ta zavdannya, T. 2. Viys'kovo-tekhnichne spivrobitnytstvo v systemi zabezpechennya voyennoyi bezpeky derzhavy" [Theory of armaments. Scientific and technical problems and tasks, Vol. 2. Military-technical cooperation in the system of military security of the state], Dmytro Burago Publishing House, Kyiv, 404 p.

3. Chepkov, I.B., Zubarev, V.V. and Borokhvostov, V.K. (2018), "Teoriya ozbroyennya. Naukovo-tekhnichni problemy ta zavdannya, T. 6, Voyenno-ekonomichnyy analiz zhyttyevoho tsyklu ozbroyennya ta viys'kovoyi tekhniky: teoretykometodolohichni zasady" [Theory of armaments. Scientific and technical problems and tasks. Vol. 6. Military-economic analysis of the life cycle of armaments and military equipment: theoretical and methodological principles], Dmytro Burago Publishing House, Kyiv, $475 \mathrm{p}$.

4. Vladimirov, A.N. (2013), "Osnovy obshchey teoryy voyny, Chast' I: Osnovy teoryy voyny" [Fundamentals of the general theory of war, Part I, Fundamentals of the theory of war], Synergy, Moscow, 832 p.

5. Vladimirov, A.N. (2013) "Osnovy obshchey teoryy voyny, Chast' II: Osnovy teoryy, praktyky y yskusstva upravlenyya hosudarstvom" [Fundamentals of the general theory of war, Part II: Fundamentals of theory, practice and art of government], Synergy, Moscow, 976 p.

6. Karyagin, V.V. and Kozin, V.P. (2014), "Voyennaya politika i strategiya SSHA v geopoliticheskoy dinamike XXI veka" [Military policy and strategy of the United States in the geopolitical dynamics of the XXI century], Granitsa, Moscow, $368 \mathrm{p}$.

7. Fedorovich, V.A., Muravnik, V.B. and Bochkarev, O.N. (2013), "SSHA: voyennaya ekonomika (organizatsiya $i$ upravleniye)" [USA: military economy (organization and management)], International relationships, Moscow, $616 \mathrm{p}$.

8. Sidorin, A.N., Prischepov, V.M. and Akulenko, V.P. (2013), "Vooruzhennyye sily SSHA v XXI veke: voyennoteoreticheskiy trud" [US Armed Forces in the 21st Century: A Military Theoretical Work], Cumulus field, Moscow, $800 \mathrm{p}$.

9. Rogozin, D.O., Sheremet, I.A., Garbun, S.V. and Gubinsky, A.M. (2013), "Vysokiye tekhnologii v SSHA: Opyt ministerstva oborony i drugikh vedomstv" [High technologies in the USA: The experience of the Ministry of Defense and other departments], Publishing house of MU, Moscow, $384 \mathrm{p}$.

10. Demidov, B.A., Korostylev, O.P., Ostapenko, S.N. and Mushroom, D.A. (2016), "Metodicheskiye osnovy sistemnykh issledovaniy i resheniya problem tekhnicheskogo osnashcheniya vooruzhennykh sil gosudarstva, Kniga 1" [Methodological foundations of systemic research and solution of problems of technical equipment of the armed forces of the state, Book 1], Stilos, Kyiv, 655 p.

11. Demidov, B.A., Ostapenko, S.N., Luhanin, M.I. and Velichko, A.F. (2014), "Sistemno-kontseptual'nyye osnovy voyenno-nauchnykh issledovaniy i resheniya prikladnykh voyenno-tekhnicheskikh problem" [System-conceptual foundations of military scientific research and the solution of applied military-technical problems] ZNPAO, Tver, $688 \mathrm{p}$.

12. Burenok, V.M., Pogrebnyak, A.V. and Skotnikov, A.M. (2010), "Metodologiya obosnovaniya perspektiv razvitiya sredstv vooruzhennoy bor'by obshchego naznacheniya" [Methodology for substantiating the prospects for the development of general-purpose weapons], Mashinostroenie, Moscow, 368 p.

13. Zhuravlev, A.V. (2002), "Teoriya upravleniya razvitiyem vooruzheniya" [The theory of arms development control], Strategic Missile Forces named after Peter the Great, Moscow, $221 \mathrm{p}$.

14. State Standart of Ukraine (2019), "VP 15.004: Systema rozroblennya i postavlennya na vyrobnytstvo ozbroyennya ta viys'kovoyi tekhniky. Stadiyi zhyttyevoho tsyklu ozbroyennya ta viys'kovoyi tekhniky" [VP 15.004: System of development and supply for the production of weapons and military equipment. Stages of the life cycle of armaments and military equipment].

15. State Standart of Ukraine (2016), "ISO/IEC/IEEE 15288: Inzheneriya system i prohramnoho zabezpechennya. Protsesy zhyttyevoho tsyklu system" [ISO/IEC/IEEE 15288: Systems and software engineering. Systems life cycle processes].

16. State Standart of Ukraine (2018), "ISO/IEC TS 24748-1: Inzheneriya system i prohramnykh zasobiv. Keruvannya zhyttyevym tsyklom. Chastyna 1. Nastanovy shchodo keruvannya zhyttyevym tsyklom" [ISO/IEC TS 24748-1: Systems and software engineering. Life cycle management. Part 1. Guidelines for life cycle management].

17. AAP-20:2015 NATO Programme Management Framework (NATO Life Cycle Model). 
18. AAP-48:2019 NATO System Life Cycle Processes.

19. ALP-10:2011 NATO Guidance on Integrated Logistic Support for Multinational Armament Programmes.

20. Gultyaev, A.A., Sirenko, V.E., and Chernega, M.A. (2017), "Problemy tsinoutvorennya na produktsiyu viys'kovoho pryznachennya ta mozhlyvi pidkhody do yikhn'oho rozv"yazannya" [Problems of pricing for military products and possible approaches to their solution], Arms and Military Equipment, No. 4(16), pp.11-19.

21. Demidov, B.O., Velichko, O.F., Grib, D.A., Lukhanin, M.I. and Korostelov, O.P. (2018), "Metodolohichni y systemotekhnichni aspekty informatsiynoho zabezpechennya upravlinnya systemamy viys'kovoho pryznachennya ta diyal'nistyu $v$ oboronniy sferi" [Methodological and system-technical aspects of information support for the management of military systems and activities in the defense sphere], Stilos Publishing House, Kyiv, $624 \mathrm{p}$.

22. Glovin, O.O., Zirka, M.V., Cadet, N.P. and Kotsyuruba, N.M. (2019), "Metodyka nechitkoho otsinyuvannya dlya system pidtrymky pryynyattya proyektnykh rishen' na etapakh stvorennya zrazkiv ozbroyennya i viys'kovoyi tekhniky" [Methods of fuzzy evaluation for design decision support systems at the stages of creating samples of weapons and military equipment], Weapons and Military Equipment, № 3(23), pp. 99-109.

23. Semenenko, O.M., Vodchits, O.G., Boyko, R.V., Dobrovolsky, Yu.B., Maslovsky, S.S. and Korochkin, O.A. (2018), "Metodychni rekomendatsiyi shchodo formuvannya metodolohiyi voyenno-ekonomichnoho obgruntuvannya (suprovodzhennya) prohram rozvytku Zbroynykh Syl Ukrayiny" [Methodical recommendations for the formation of the methodology of militaryeconomic substantiation (support) of development programs of the Armed Forces of Ukraine], Weapons Systems and Military Equipment, No. 2(54), pp. 142-150. https://doi.org/10.30748/soivt.2018.54.20.

24. Turinsky, O.V., Demidov, B.O., Grib, D.A. and Khmelevska, O.O. (2020), "Metodychni aspekty planuvannya rozvytku system ozbroyennya protypovitryanoyi oborony $\mathrm{v}$ umovakh resursnoho obmezhennya" [Methodical aspects of planning the development of air defense weapons systems in terms of resource constraints], Science and Technology of the Air Force of Ukraine, No. 1(38), pp. 61-71.

25. ALCCP-1:2008 NATO Guidance on Life Cycle Costs.

26. AUIDP-1 NATO Guidance on Unique Identification (UID) of Items Ed.B Version 1.

27. ISO 10303-239:2005 Industrial Automation Systems and Integration - Product Data Representation and ExchangePart 239: Application Protocol: Product Life Cycle Support.

\section{Відомості про авторів:}

Гриб Дмитро Анатолійович

кандидат військових наук доцент

головний науковий співробітник

Харківського національного університету

Повітряних Сил ім. І. Кожедуба,

Харків, Україна

https://orcid.org/0000-0001-8478-978X

\section{Демідов Борис Олексійович}

доктор технічних наук професор

провідний науковий співробітник

Харківського національного університету

Повітряних Сил ім. І. Кожедуба,

Харків, Україна

https://orcid.org/0000-0003-1728-6925

\section{Кулагін Костянтин Костянтинович}

кандидат технічних наук

старший науковий співробітник

начальник науково-дослідного відділу

Харківського національного університету

Повітряних Сил ім. І.Кожедуба,

м. Харків, Україна

https:// orcid.org/0000-003-1189-5623

\section{Хмелевська Ольга Олександрівна}

кандидат технічних наук

старший науковий співробітник

провідний науковий співробітник

Харківського національного університету

Повітряних Сил ім. І. Кожедуба,

Харків, Україна

https://orcid.org/0000-0001-9018-5552

\section{Information about the authors:}

Dmytro Grib

Candidate of Military Sciences

Associate Professor

Chief Scientist of Ivan Kozhedub

Kharkiv National Air Force University,

Kharkiv, Ukraine

https://orcid.org/0000-0001-8478-978X

\section{Boris Demidov}

Doctor of Technical Sciences

Professor Lead Researcher

of Ivan Kozhedub Kharkiv National

Air Force University,

Kharkiv, Ukraine

https://orcid.org/0000-0003-1728-6925

\section{Konstantin Kulagin}

Candidate of Technical Sciences

Senior Researcher

Head of the Research Department of

Ivan Kozhedub Kharkiv National

Air Force University,

Kharkiv, Ukraine

https:// orcid.org/0000-003-1189-5623

\section{Olga Khmelevcka}

Candidate of Technical Sciences

Senior Research

Lead Researcher of

Ivan Kozhedub Kharkiv National

Air Force University,

Kharkiv, Ukraine

https://orcid.org/0000-0001-9018-5552 
ПРОБЛЕМНЫЕ АСПЕКТЫ НАУЧНО-ТЕХНИЧЕСКОГО СОПРОВОЖДЕНИЯ ПРОЦЕССА УПРАВЛЕНИЯ ПОЛНЫМ ЖИЗНЕННЫМ ЦИКЛОМ СЛОЖНЫХ ОБРАЗЦОВ ВООРУЖЕНИЯ И ВОЕННОЙ ТЕХНИКИ

Д.А. Гриб, Б.А. Демидов, К.К. Кулагин, О.А. Хмелевская

В статье в систематизированном виде представлены основные проблемные аспекты, решаюшиеся в ведущих странах мира, при научно-техническом сопровождении прочесса управления полным жизненным циклом (ЖЦ) сложных образиов вооружения и военной техники (BВT). Рассмотрены особенности построения системы управления полным ЖЦ. Выделены следующие важные свойства системы и ее процесса управления как возможность прослеживания состояния образиа ВВТ на всех стадиях его ЖЦ и бережливости всех стадий ЖЦ в иелом. Представлены некоторые иелесообразные подходы к ослаблению негативного влияния факторов риска, возникаюших как на стратегическом, так и на оперативном уровнях управления. Обозначено, что разработка и использование автоматизированных систем управления полным ЖЦ образцов ВВТ могут быть признаны перспективным направлением оптимизации затрат ресурсов на поддержание необходимого уровня качества системы вооружения вооруженных сил государства в иелом и ее основных подсистем. Доказана необходимость оперативного реагирования на ситуации, которые возникают и поддержания при этом стратегической направленности управления полного ЖЦ образиов ВВТ, что требует согласованного программно-иелевого и ситуачионного управления ЖЦ В рамках единого программно-ситуачионного подхода $к$ управлению, вместе с созданием информачионной среды полного ЖЦ и межведомственных нормативных документов (стандартов), определяющих концептуальную, функииональную и информационную модели системь управления полным ЖЦ. Управленческие решения по формированию содержания и продолжительности ЖЦ и перехода к следуюшим его стадий должны обеспечивать бережливость ЖЦ систем вооружения вооруженных сил в целом.

Ключевые слова: полный жизненный ичикл образиа ВВТ, система управления полным жизненным ичиклом, бережливость жизненного ичикла, прослеживаемость жизненного циикла, стратегический (оперативный) уровень управления.

\section{PROBLEM ASPECTS OF SCIENTIFIC AND TECHNICAL SUPPORT OF THE PROCESS OF MANAGING THE COMPLETE LIFE CYCLE OF COMPLEX SAMPLES OF WEAPONS AND WAXES}

D. Grib, B. Demidov, K. Kulagin, O. Khmelevcka

The article presents in a systematic way the main problematic aspects that are solved in the leading countries of the world, with scientific and technical support of the process of full life cycle management (LC) of complex models of weapons and military equipment (WEE). Features of construction of control system of full LF are considered. Such important properties of the system and its management process as the possibility of tracking the state of the sample of weapons at all stages of its LF and the savings of all stages of the LF in general are highlighted. Some useful approaches to mitigating the negative impact of risk factors that arise at both the strategic and operational levels of management are presented. It is noted that the development and use of automated control systems for full LC samples of weapons can be considered a promising area of optimizing resource costs to maintain the required level of quality of the armament system of the armed forces as a whole and its main subsystems. The necessity of operative reaction to the arising situations and maintenance at the same time of strategic orientation of management of full LC of samples of IE, which requires the coordinated program-target and situational management of LF within the uniform program-situational approach to management, together with creation of information environment of full LF and interdepartmental normative documents (standards) that define the conceptual, functional and information models of the management system of the PJC. Management decisions on the formation of the content and duration of the LF and the transition to its next stages should ensure the economy of the LC of the weapons systems of the armed forces as a whole.

Keywords: full life cycle of the sample of weapons, full life cycle management system, life cycle economy, traceability of the life cycle, strategic (operational) level of management. 